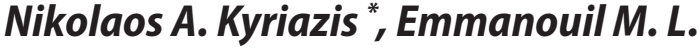 \\ Economou **
}

\section{Brexit and new perspectives of an unconventional way of Eurozone revival}

\begin{abstract}
In the aftermath of the UK referendum on June $23^{\text {rd }}$, 2016 that resulted in a sonorous negative decision regarding the willingness of the British people to remain in the EU, a significant number of alarming questions have emerged. Although Europe should have forged in crises, nowadays, many compromises have to be made in order to maintain the European construction as intact as possible. The question we attempt to answer is whether a new phase of unconventional monetary policy in the form of QE would be appropriate to lessen the threat of an upcoming crisis. This is why we examine Eurozone QE perspectives through the prism of the new EU era without the UK in order to highlight the pros and cons of the historical Brexit decision. As new rounds of unconventional monetary policy are believed to be essential for supporting the weaker countries in the European south, perspectives of nonconventional success could alter and optimal policies be substantially reformulated subject to the newly-arising constraints. Based on the main scenarios about the UK's relations to the European Union in the near future, we estimate how a new round of non-conventional measures could affect the Britons as well as the European citizens. Moreover, we try to assess the viability of each of these outcomes through the spectrum of a monetary-driven decision-making.
\end{abstract}

Keywords: Brexit, European Union, Quantitative Easing, Eurozone

JEL Classification: E58, E52, F41
* Department of Economics, University of Thessaly, Volos, Greece

${ }^{* *}$ Department of Economics, University of Thessaly, Volos, Greece

E-mail (corresponding author): emmoikon@uth.gr 


\section{Introduction}

There is a growing tendency among economic agents to argue that harsh economic shocks - such as the result of the recent referendum in the UK that is taking Britain out of the European Union (EU) - render unconventional monetary policies more necessary than before. This holds because of the UK being large and important enough to create an upheaval on a European, or even a global scale, due to its systemic importance in the financial and economic sectors.

Brexit was a real shock to many scholars, economists and political thinkers. Many of them thought that it might be only the tip of the iceberg: once the door opened it might lead to many EU countries to follow the British path for a variety of socio-economic reasons (Grexit - Greece, Nexit - Netherlands etc.).

However, some others believe that Brexit may give the EU the opportunity to increase its coherence since the UK was always between the European and Anglo-Saxon road and they argued that sometime in the future, which is now, the British would finally decide to choose sides. If this belief is true, it may mean that Brexit was a phenomenon that took place for a specific set of historical and socio-economic reasons. Once Brexit happened, many Euroscepticists demanded referendums to be held in their countries for the same reasons. ${ }^{1}$ Would the same happen in France and the Netherlands, two historically strong "pillars" of European unification? Furthermore, southern EU countries (Spain, Portugal, Italy, Cyprus) as well as other members, are facing much discomfort by the European Union's economic policies.

This paper is an attempt to answer whether a new phase of unconventional monetary policy in the form of $\mathrm{QE}$ would be appropriate to lessen the threat of an upcoming crisis. Unconventional monetary policymaking in the UK and the Eurozone has been the centre of a proliferating bulk of academic studies such as in Kyriazis (2017) and Kyriazis and Economou (2017). The paper is organized as follows: Section 2 describes the main policy scenarios about the relation of the UK with the European Union after the Brexit decision. Section 3 concerns how the monetary policy of the UK and the EU could alter due to Brexit. In Section 3, a detailed description of QE-related perspectives in the UK as well as in the Eurozone under the new Brexit-led constraints is given, in order for a clearer

\footnotetext{
1 http://metro.co.uk/2016/06/24/could-nexit-follow-brexit-dutch-mp-calls-for-referendum-5964035/

http://www.nltimes.nl/2016/06/24/wake-brexit-vote-wilders-calls-dutch-nexit/
} 
picture of the most or less probable scenarios in the near or more distant future to be presented. Section 4 analyses further the issue of the UK connection to the EU and QE perspectives. Finally, conclusions about the post-Brexit newly-arising era are made in Section 5.

\section{Will Brexit alter the character of UK and the EU strategies concerning monetary issues?}

Just after the result of the referendum was publicized, the Bank of England announced that it had an excessive contingency plan and was working closely with the HM Treasury. The expensive imports from now on will impose inflationary pressures that might work as an impediment to the abrupt downfall of the sterling exchange rate. The sterling devaluation as a consequence of Brexit has nothing to do with a reduced intrinsic value in the current fiat money environment, but with a lower credibility on the part of British authorities.

This is derived from the surge in unreliability of the latter, as exiting the EU forms a major step back, and this decision has induced a great level of extra volatility in the UK financial market. This is in contrast to the higher stability in the UK's financial markets that recent institutional reforms have brought about such as the formation of the Monetary Policy Committee (MPC), according to Nasir et al. (2017). As an immediate consequence of leaving the EU, the euro will become a safer asset whereas the sterling will become undervalued. Convincingly enough, this will lead the UK to a long-lasting competitive advantage, whereas the already afflicted by the euro-crisis European market will suffocate by a lack of competitiveness due to the high prices that British importers will have to pay for European products in terms of sterling. Moreover, levels of credibility in the EU will be downgraded, as Brexit will increase the probability assigned to other members also leaving. This will inevitably boost the country-risk in each of the EU members and in the EU as a whole, raising risk premiums. Apart from the lack of cooperation between governments and central banks, growing Brexit-induced pessimism is reinforced and to blame for the risk of economic languishment.

It is noteworthy that economic growth was expected to be zero in the UK for a number of quarters. Economy expanded at about $0.5 \%$ in the three months after 
the Brexit vote. ${ }^{2}$ The UK current account deficit equals $7 \%$ and a sterling devaluation could highly likely prove beneficial for its curtailing. A steep decline in the value of the sterling though, may induce businesses to take advantage of possible extensive arbitrage revenues and prefer to keep these profits in their pockets. Differently expressed, profit made due to the Brexit-caused exchange rate movements has a high probability of not being reinvested on a low price - high quality policy. This will therefore shrink economic growth. In such an economic recrudescence, the Bank of England would be forced to acquire an intensified quasi-fiscal role by injecting liquidity into the UK markets, probably in the form of a new QE-type round.

Europe's financial capital the day after Brexit, provoked an immense fall in British banks' share prices, especially in large systemic banks such as Lloyd's and Barclays. All this happened in conditions of fear about an imminent credit degradation of the UK by S\&P rating agency. Endeavouring a smoother transition to the post-Brexit era, the terms of the UK's leaving the EU should be negotiated in such a way that the benefits from HSBC, Goldman Sacks and JP Morgan building new headquarters in London, would not be wasted for the EU or for the UK.

This is why a term used alongside with Brexit has been "Lexit", meaning that the UK leaving the EU would also mean the City of London financial centre losing a large part of its status and its leading role in global markets. ${ }^{3}$ Although a significant reduction of London's influence on the markets of Germany, France, Ireland or Luxembourg now seems inevitable, the exit should be adjusted by legislation in order for Brexit not to prove catastrophic for either party. The overall downturn in financial markets that made its appearance approximately eight years ago should by no means be repeated.

2 According to Bloomberg, the UK economy slowed less than economists' forecast in the quarter after the Brexit vote because of a surge in services, providing ammunition for critics of those who warned of a possible fallout before the referendum. See https://www.bloomberg.com/ news/articles/2016-10-27/u-k-economy-proves-resilient-to-brexit-with-hollywood-s-help and https://www.ft.com/content/bab284e4-9cld-11e6-a6e4-8b8e77dd083a

3 Some economists think that the City of London's high turnover financial enterprises in banking, insurance and asset management will be harmed by Brexit. It is possible that a critical amount of such companies may be transferred to cities such as Paris, Brussels, Amsterdam, Dublin and certainly to Frankfurt, which has the special privilege of having the headquarters of the ECB.

See http://www.ft.com/cms/s/2/f44e8a6e-2f2a-11e6-bf8d-26294ad519fc.html http://www.independent.co.uk/news/business/news/paris-frankfurt-amsterdam-dublin-brussels-new-london-brexit-eu-referendum-global-financial-centre-a7113266.html 
It is fairly possible though, that Brexit will have consequences beyond the boundaries of the UK. Apparently, an overvaluation of the yen in relation to the sterling will damage the Japanese economy that is already suffering from high deflationary levels and a very high public debt. On the day following the referendum in the UK, the German 10-year government bond yields fell to a record low of minus 10 basis points due to the immediately activated "flight-to-safety" sentiment of investors.

On the other hand, the risk of indebted countries (such as Italy, Spain, Portugal and Greece) exiting the European Monetary Union has brought to the surface upward movements of their bond yields, making these regions to be considered even riskier. There is admittedly an easily perceivable risk that higher bond yields discounting equity holdings will reduce the assets' value and increase their liabilities' value. In other words, net values will fall and solvency problems will emerge. A significant example is the UK corporate pension deficit that has widened by $£ 80$ million overnight (that is 10 times the annual EU budget contribution).

\section{Perspectives and consequences after the Brexit}

\subsection{UK perspectives after leaving the EU}

In 2010-2014, the UK had total exports amounting to the $2.9 \%$ of the UK's GDP 4 whereas its imports constituted only $2.4 \%$ of the GDP. The main sectors of exchanges were vehicles, machines and chemicals that formed about three quarters of the total transactions.

During the last 15 years, more than $20 \%$ of the inward European foreign direct investments have been given to the UK even though these had no full access to the EU's internal markets. Their main destination was the UK car industry. After the Brexit decision, it is reasonable that this money could effectively be used to help other European countries, thus depriving British of a significant assistance. On the other hand, the UK will benefit by the fact that after Brexit, British tax-

${ }^{4}$ http://voxeu.org/article/implications-brexit-rest-eu 
payers will not be burdened anymore by contributions to the EU's overall budget. The UK spent 15 billion euros in 2015 out of a total of 142.1 EU-28 billion euros. ${ }^{5}$

A scenario strongly promoted by supporters of Brexit is that if the UK were able to abolish all import tariffs after leaving the EU, this could obstruct a significant rise in GDP, perhaps large enough to offset the consequences of a devaluation of sterling. This would be difficult to realize, though.

Moreover, if the depreciation proved to be large enough, tariff reduction would end up having no significant impact overall. This way, consumption and wealth effects emerging by larger and cheaper imports would be counterbalanced by lower income due to a weaker pound. This could turn the other way round if and only if the higher volume of exports was large enough. In addition, Britain's exports to the EU and to other members of the World Trade Organization (WTO) would have to suffer tariffs and be subject to regulation of the WTO. The latter has not managed to liberalize markets as much as the EU, so EU markets would have less access to UK producers. ${ }^{6}$

Unconventional monetary policy is again the most highly estimated candidate to remedy this extensively debatable situation. Quantitative Easing $(\mathrm{QE})$ could provide an additional stimulus in order for the UK to attain economic sanity under the new spectrum of challenges. The further impetus that the UK economy will require may result in lower levels of interest rates, even flirting with a negative sign. This would inevitably pose a threat on building societies that heavily rely on funding by deposits and mainly make mortgage lending. This is why a new round of liquidity-injecting expansionary monetary policy in the form of QE has a high probability to emerge as a solution. The lack of confidence engendered by the Brexit announcement may even call for irredeemable money injections in the form of helicopter money drops. ${ }^{7}$

5 However, it must be acknowledged that since 1984 the UK has been receiving a refund on a part of its contribution to the EU budget, the so-called rebate.

See http://news.bbc.co.uk/2/hi/europe/8036802.stm https://www.gov.uk/government/uploads/system/uploads/attachment_data/file/483344/EU_ finances_2015_final_web_09122015.pdf

After Brexit the $27 \mathrm{EU}$ member's states must provide a larger amount of money to cover the EU budget. Obviously, this will be achieved through further taxation in each member-state.

${ }^{6}$ http://www.voxeu.org/article/life-after-brexit-uk-s-options-outside-eu

7 Helicopter money is referred to a policy where a government prints money to try to spur growth and get inflation higher. It is an idea based on a metaphor used by the renowned economist Milton Friedman nearly five decades ago and given new life in this century by Ben Bernanke, ex-Fed Chairman. 
Estimations about the new round of QE needs are about $£ 100-150$ billion $^{8}$, a little less than half of the aggregate liquidity injections of $£ 375$ billion during the past three QE rounds. A probable stimulatory scenario would be expanding the Funding Lending Scheme (FLS), which the Treasury and the BOE initiated in 2012 in order to provide growth-generating liquidity to British banks. Hopefully, this new money would be diffused to reliable enterprises in the form of low-risk credit. It should be noted that leaving the EU renders assets illiquid and urges British investors (including banks) to take on riskier investments in order to achieve higher profits.

The undesired corollary of this is greater instability in the UK financial system. This would form a good reason for the British government to guarantee bank deposits, under the conditions that moral hazard problems could be limited.

\subsection{European perspectives after Brexit and the ghost of a further Euroexit}

As regards the effects of Brexit on the EU and the EMU, a scenario of an additional level of unconventional monetary practices should be taken into consideration. Nevertheless, it should not be neglected that the UK leaving the EU could affect the embryonic stage of QE where the EU lies in, via most of its channels.

Large-scale asset purchases could be perceived as a sign of a desperate attempt to maintain sanity in the European financial system, after the EU having lost one of its most prominent members. Moreover, due to Brexit, economic agents would tend to prefer holding safer assets (flight-to-safety) in their portfolios, thereby reducing the efficacy of the portfolio rebalancing effect that is favourable for liquidity. Apart from that, confidence would be very low as regards the European perspectives.

The yield curve would not flatten as it should, and asset prices would fall, lessening the so-confoundedly desired QE wealth effect strength. Additionally, conventional forward guidance policy would become highly unreliable due to the aggravation of time-inconsistency problems in tandem with a higher probability of adverse exit shocks showing up. Unavoidably, the potential of further exits from the EU or the Eurozone would make the EMU step more intensely and hazardous into uncharted territory.

8 http://www.economist.com/news/britain/21701260-britain-faces-months-economic-uncertainty-implications-brexit-bank-england 
Interestingly enough, there is some share of thinking, though not a voluminous one, supporting that Brexit could prove stimulatory for the bank-centric Eurozone (EZ) countries, due to the competitive advantage that would bring for the UK. On the other hand, exports to the UK will be very difficult to conduct. It also has to be taken into consideration that a great decline in the EZ credibility due to Brexit may provoke a need for even more restrictive monetary policies by the ECB and even stricter fiscal policies imposed to European national governments.

This would render sovereign debts even harder to handle and would probably increase incentives to leave the EZ. Due to the non-linearity (domino effect) of motivations to leave a union or abandon a policy rule during a crisis and also due to credibility losses, it is quite possible that a new financial crisis could show up. Consequently, unconventional monetary policies would then become indispensable to a larger degree, even though their efficacy would be lower than before as this would not be the first round of QE.

The EU should not apply its external customs duties on UK goods and services or erect regulations and licenses as impediments in free-trading with the UK. The possibility of imposing material restrictions on the UK's ability to conduct transactions in euros, as well as in euro-derivatives would be extremely harmful. Greater transaction costs between the UK and the EU would bring again a form of returning to barter-like exchanges, reducing the elasticity between trades.

There is a growing fear that Brexit is likely to intensify inequalities between EU members. This would be translated into the remaining members getting a larger share of the European economic activity and a higher burden concerning the participation of each member's participation and contribution in the overall EU's budget, although the smaller of them could be harmed. Bearing in mind that the UK is a net contributor, total income in the EU will fall, and a smaller part of that will be given to poorer countries of the EU. The oligopolistic powers of the powerful European members are likely to be fortified, also strengthening the credibility of the ECB.

On the other hand, southern countries will become even more vulnerable to imposition of the powerful countries' decisions. This has to do with the possibility that the economically strong member-states such as Germany (which will strengthen its main position as the main economic steam-engine of the EU after Brexit) may be less willing to negotiate concerning the alleviation of austerity measures as far as the weak economy EU member states such as Greece are concerned. Why? Because, according to some thinkers, after Brexit, any more reluctance and "tolerance" by the strong EU members, which so far have heavily sub- 
sidized (through their own taxpayers) the financial mechanisms of the European Stability Mechanism (ESM) and the European Financial Stability Facility (EFSF) may be regarded as a sign of weakness.

So far, concerning the EMU and ECB realities, "chicken game" strategies have proven ineffective when trying to be implemented by the economically weak to the strong member states. The recent July 2015 failed Greek government plans to make the EU institutions and the IMF accept its own terms during negotiations with the EU Commission, the EMU and the IMF before the establishment of the $3^{\text {rd }}$ Greek MoU of July 2015 (which was finally accompanied by an 86 billion bailout package under the aegis of the EU institutions and the IMF) is proof of such a view. ${ }^{9}$

But there is also another extreme possibility: in order to show a sign of strength, unity and no affection by Brexit, the rest of the economically strong EU members states (Germany, France, etc.) may "overdo" it in the sense of demanding more and more austerity measures to be undertaken by the governments of the economically weak member-states, as an exchange for agreeing to contribute to any kind of future bailout packages under the aegis of the ECB. This may seem to be a "carrot and stick strategy": any more lending may materialize providing that weak states accept harsher austerity measures (which are, of course, part of further strict neoliberal economic doctrines, if seen from a wider economic policy perspective).

What such a policy may not seriously takes into account is that it carries the risk of further possible Euroexit scenarios, as a self-fulfilling prophecy: the economically strong EU members may think that since there is a possibility of exit on the part of many EU economically weak countries, the latter must be threatened by further economic measures ${ }^{10}$, and then succumb to their fears, in order to adopt more "realistic" (austerity) economic policy strategies on the national level. But such a strategy, if it can be imposed by the strong members on the weak ones, does not seriously take into account the fact that austerity measures cannot be acceptable forever by people in the EZ member-states and particularly by the citizens in countries with already harmed economies such as Greece, Cyprus, Italy, Spain, Portugal etc., i.e. the southern EU member-states. The politico-economic "prestige" of the EU in these countries may further erode in a critical level, which might finally lead to a new exit case such as Brexit.

9 On this issue concerning the Greek case see http://www.ft.com/cms/s/0/0b340146-b20e-11e4b380-00144feab7de.html and Kyriazis and Economou (2016).

${ }^{10}$ However, we avoid calling them "sanctions". 
Thus, we argue that if EMU austerity policies are finally strengthened in the short-, or even long-term, then European countries with high sovereign debts (such as those mentioned above) would become even more motivated to leave the Eurozone or even the EU. This is why a new financial "remedy" might be a tangible solution: a round of QE has to be implemented by the ECB. Although the UK was not part of the Eurozone, its being a member-state of the EU was undoubtedly a major influence on power-sharing inside and on the credibility of the euro area. Major economists such as M. Friedman (2005) have supported monetary expansions such as helicopter money drops and considered them highly effective.

As it has already been mentioned above, until now, the Eurozone has created the European Stability Mechanism and has introduced the Outright Monetary Transaction Scheme (OMT) in order to handle the financial crisis. Additionally, it has imposed stricter surveillance legislation in order for a banking union to become feasible. This framework has to be further strengthened in the wake of the EU not having the UK as its member. ${ }^{11}$

A good point about the Eurozone is that the extensive regulation has left little space for national governments to influence European decision-making and to threaten the monetary and fiscal cohesion inside the EU. Unfortunately, the Macroeconomic Imbalances Procedures (MIP) have not been very effective in confronting the Current Account Imbalances. Neither was the Single Supervisory Mechanism reform effective for banks. Moreover, the Stability and Growth Pact and the Treaty on Stability, Coordination and Governance in the EMU (also called the Fiscal Stability Theory) that followed, has resulted in an even more complex framework and failed to provide a set of transparent and applicable rules. This lack of credibility in the EMU, combined with Brexit, raises concerns about one or more indebted countries leaving the EMU.

Bearing in mind the greater propensity to exit that EMU-members present because of the increasing burden of fiscal, economic and financial constraints, immediate fire-fighting measures should be taken. Another exit from the EU would

\footnotetext{
${ }^{11}$ The European banking union is an important step towards a genuine Economic and Monetary Union because it will allow for the consistent application of EU banking rules in the participating countries. The new decision-making procedures and tools help to create a more transparent, unified and safer market for banks. See https://www.bankingsupervision.europa.eu/about/ bankingunion/html/index.en.html

The procedure towards a banking union has already started. However, there is still an open issue of offering guarantee to all banks throughout the EU, meaning that if a bank in a member state faces problems, deposits of its depositors are still not guaranteed by a pan-European Banking authority.
} 
be a major shock to the world's trade and credit, because the trust in the EU could never be betrayed without profound moral and economic reactions. The UK, having made the first step towards instability of the EU, a possible not easing of austerity would lead the Eurozone members out of the Eurozone, by a much greater probability. Brexit will likely cause "beggar-thy-neighbour" phenomena due to the devalued sterling, as the UK trading partners will lose if devaluations are seen as a zero-sum game, which is often the rule. The same thing would go if another member left the EU or the Eurozone.

\subsection{Is there a remedy? Towards a more flexible ECB monetary policy?}

Not surprisingly, there could be a clear way for a policy of "cheap money" to become a remedy under these adverse conditions. Brexit has fortified the increasing consensus that debt forgiveness is more necessary than ever, no matter if this would be proper through moral lens. ${ }^{12}$ The acrimonious debate about the restructuring of southern European countries' sovereign debts should be done with respect to the dual mandate of the EMU about low inflation and non-mutualization of government debts.

A compromising solution leading to looser fiscal restrictions imposed by the EU, combined with an easier EMU monetary policy, could lead to a wealth increase even for indebted countries (Del Negro and Sims, 2015) and help to render the EU tissue tighter again. On the contrary, low growth remaining in this particular moment of time could increase economic inequalities and austerity and thus, strengthen Euroscepticism and eventually it will possibly lead to the fragmentation of the EMU and the EU.

The trilemma of Pisani-Ferry (2012) makes its appearance once again, highlighting the great difficulty in attaining at the same time a European fiscal union, a European banking union ${ }^{13}$, and the ECB acting as the lender of last resort for sovereigns. A government debt restructuring would have devastating consequences for the banking system, because of banks' great exposure to their countries' sovereign debt. Public money should not be the first, not even the last means of supporting the banking system. Sharing of risks should be realized in early stages

\footnotetext{
${ }^{12}$ For example, Peter Bofinger (University of Wuerzburg), economic adviser to the German government is in favour of an extra debt relief in favour of the Greek economy. See http://www. bloomberg.com/news/videos/b/f42f9b6d-ef1c-41b0-bd66-0457e639055b

${ }^{13}$ For the creation of a Fiscal Union in the EU see, inter alia, Bordo et al. (2011) and Fuest and Peichl (2012). For the European Banking Union see, inter alia, de Quiros (1999), Beck (2012), Goyal et al. (2013) and Schoenmaker (2015).
} 
and in proportion to each country's share in the ECB's capital, in order for the risk-sharing to become as less unfair as possible, and decision-making as regards debt-mutualization to be characterized by the highest possible degree of unanimity.

\section{UK connection to the EU and QE perspectives}

It has to be taken into consideration that, since the onset of the financial crisis, the UK has created the Financial Policy Committee and the Prudential Regulation Authority of the Bank of England and the Financial Conduct Authority. The BOE is responsible for ensuring financial stability in the UK and is accountable to the Parliament.

The UK leaving the EU will reduce financial openness and shrink the UK's financial system, but will leave it with a lower level of complexity and less vulnerable to external shocks. Legislation and regulatory matters will increasingly become a British responsibility, thereby reducing the credibility the UK financial system had as an EU-standardized safe system. Special attention should be attributed to the great extent of interdependency between the UK and the EU, as half of the former's trades (worth approximately $30 \%$ of the UK's GDP) are conducted with the latter. Two-thirds of European imports of the UK are from Germany and it is noteworthy that the spreads margin reflecting the safety ratings difference between the two countries will be considerably increased.

Regarding labour dynamics, the stricter legislation will also be an impediment for the growth of the British economy. It should be kept in mind that about 1.3 million British people live and work in the EU, whereas 3 million European people live and work in the UK. It is reasonably expected that labour rigidities will provoke dysfunctions in the goods, services, capital and labour markets by reducing the UK's economy and its market size, and lowering competition.

The matching of capital and labour will become costly in the UK and British enterprises will conform to a poorer level of specialization and shrinkage in the Research and Development sectors. Migration flows will be restricted due to the loss of EU citizenship in the UK, so capital mobility will lose its primary lubricant. Microprudential and macroprudential policy set by the Bank of England will be less influenced by EU laws ${ }^{14}$, thus bringing lower credibility in the financial system, despite EU regulations not being considered as strict ones. It is remarkable

\footnotetext{
${ }^{14}$ http://www.bankofengland.co.uk/publications/Documents/speeches/2015/euboe211015.pdf
} 
that since the subprime crisis occurred, the UK credit default swap premiums (which constitute a measure for the bank credit risk) with comparison to the EU ones, have risen significantly and not fallen thereafter. This suggests a high level of interconnection between the two areas. Moreover, a non-negligible part of the UK's relationship with the EU's risk is expected to remain intact because the adoption of the OECD's Code of Liberalization of Capital Movements does not leave wide possibilities of policy differentiation between members and nonmembers of the EU.

Thus, a new and more substantial round of QE in the Eurozone could probably urge investors to increase their demand for substitutes such as UK and US government bonds, thereby increasing UK's bond prices and lowering their yields. This would stimulate inflationary pressures inside the United Kingdom. On the other hand, Brexit could accelerate the UK transition towards a new phase of QE in order to boost the British aggregate demand. Utilization of the Funding for Lending Scheme (FLS) could be used once more in order to reduce funding costs in the UK, with the cost of inflationary pressures showing up. QE actions adopted by the Bank of England could bring beneficial effects not only for the UK but also for the EU because fewer shocks from the former could hit the latter. The same can be said for the other way round.

Further unconventional monetary measures, such as helicopter money drops in the UK should be extensively examined regarding their efficiency. Although permanent money injected into the UK economy would stimulate a more effective economic spur, the credibility of the UK's authorities would be seriously afflicted, despite being already hurt due to Brexit. No matter what, the amplitude of credibility loss should not surpass a critical level where foreigners' mistrust regarding the UK would become irreversible.

In other words, helicopter money drops should not be preferred, or at least should not be realized in a great extent. On the other hand, unconventional monetary policy in the form of long-term asset purchases could indeed be effective. This is because it could be seen as a brand new expansionary policy episode in the freshly-started post-Brexit era. This way it would not be subject to the more or less formed expectations' constraints. Differently said, the new shock that Brexit provides could alter investors' beliefs about the UK economic policy, so that the restructuring of the UK financial sector could provide with increasing efficiency levels the new round of unconventional policy.

As regards the EU, perspectives for a larger risk-sharing of national sovereign debts could become more and more welcome under conditions of the larger risk 
of an EU crack that Brexit has imposed. The so-desired achievement of a European banking union and a capital markets union in the EU could become more easily reached after Brexit, as the UK was never affirmatively positive about its willingness to be totally integrated in the European construction. Most probably, in the short-run, volatility will have high levels previously considered as outliers to become regularity, both for the UK and the EU.

In the medium-term however, when the EU becomes more focused outside the $\mathrm{UK}$ as the EU financial centre, it can render stronger and more unified than before. It can barely be doubted that one of the prerequisites of the longer-term viability in the EU is its cohesion. Quantitative easing measures could look as one of the appropriate solutions to healthfully strengthen the bank-centric character of the EU in order for better days to come. The powerful members of the EU and the Eurozone would probably again be opposed to a substantial level of money injection in fear of further moral hazard motivation evoking. Even though they should not forget that the word "pay" has its origins in the verb "to pacify".

But "pay" in the sense of creating money through QE or helicopter QE mechanisms may also be the remedy for creating jobs, if exercised prudently and not excessively by the monetary policymakers in the EU-27 and the UK, may increase people's wealth and the overall consumption, especially in those economies being under economic recession such as Greece, thus creating the opportunities for a gradual economic recovery and growth (while also facing deflation and austerity policies which harm the social cohesion throughout the EU).

Admittedly, there is enough room to support that the pacification between parts of the same body that $\mathrm{QE}$ policies can provide could be a way to come up against the double hurdles that the debt crisis and Brexit have engendered.

\section{Conclusions}

The shock from the decision of the British people to leave the EU was most likely not anticipated. It was a crucial historical benchmark which may critically undermine the planned EU integration since the UK still plays a major role in global economic and geopolitical affairs.

Views in favour of Euroscepticism, have emerged recently very rapidly with strong momentum, mainly due to austerity policies (being implemented by most of the European Union members including the UK government policymakers) that have undermined socioeconomic cohesion in these countries. We argued 
that this situation is strongly related to the mixture of monetary policies that are exercised by the ECB, the Bank of England, and the rest of the EU-member states' banks. We have also argued that due to this situation, QE policies could possibly find a way to usefully re-emerge as an arrow in the quiver of monetary authorities in order to stimulate economic recovery, both in the UK and the EU. The strong connections of the latter to the former may become looser than in the pre-Brexit era, though a significant degree of interdependence will continue to exist.

Liquidity injecting, without causing serious harmful effects on the credibility of the monetary authorities in their areas, would constitute the ideal solution. Arguably enough, this could only be offered by unconventional monetary policies, such as large-scale asset purchases of a non-permanent character so as to restrain moral hazard incentives.

This paper has looked at the current circumstances through the lens of the UK's relationship with the EU. According to our view, risk-sharing of European sovereign debts is likely to induce the desired pacification and cohesion in the EU and the EMU, whereas it should be noted that the UK is in need of urgent stimulatory liquidity-providing actions due to Brexit. We hope that this analysis and our suggestions may open a vast future area of research and discussion that our paper will help to promote. 


\section{References}

1. Beck, T. (2012). Banking Union for Europe. Risks and challenges. Centre for Economic Policy Research (CEPR). Retrieved at: http://www.voxeu.org/sites/ default/files/file/Banking_Union.pdf

2. Bordo, M.D, Markiewicz, A. \& Jonung, L. (2011). A Fiscal Union for the Euro: Some lessons from history. NBER Working Paper No. 17380. Retrieved at: http://www.nber.org/papers/w17380.pdf

3. de Quiros, L.B. (1999). The European Monetary Union. A political time bomb, Cato Journal 19(1): 143-160.

4. Del Negro, M., \& Sims, C.A. (2015). When does a central bank's balance sheet require fiscal support? Journal of Monetary Economics 73, 1-19.

5. Friedman, M. (2005). The optimum quantity of money. Transaction Publishers.

6. Fuest, C. \& Peichl, A (2012). European Fiscal Union: What is it? Does it work? And are there really 'no alternatives'? IZA Policy Paper No. 39. Retrieved at: http://ftp.iza.org/pp39.pdf

7. Goyal, R. Brooks, P.K., Pradhan, M., Tressel, T., Dell'Ariccia, G., Leckow, R \& Pazarbasioglu, C. (2013). A Banking Union for the euro area. IMF Staff Discussion One. Retrieved at: https://www.google.gr/?gfe_rd=cr\&ei=EwiKV_ DqD6yt8wfy4KHACg\&gws_rd=ssl\#q=european+banking+union+pdf

8. Kyriazis, N. \& Economou, E.M.L. (2016). “The memoranda trap and the near fall of Greece”, in D. Caldwell (ed.). Greece: Economic Crises and Management (pp. 75-93). New York: Nova Publishers.

9. Kyriazis, N. A. (2017). Eurozone Debt Monetization and Helicopter Money Drops: How Viable can this be?. Journal of Central Banking Theory and Practice, 6(3), 5-15.

10. Kyriazis, N. A., \& Economou, E. M. (2017). The Relation of Brexit with the UK's QE Decisions and its Impact on the Eurozone. Journal of Central Banking Theory and Practice, 6(1), 5-14.

11. Nasir, M. A., Yagob, M., Solimanc, A., \& Wud, J. (2017). Institutional Design, Macroeconomic Policy Coordination and Implications for the Financial Sector in the UK. Journal of Central Banking Theory and Practice, 6(3), 95-126.

12. Pisani-Ferry, J. (2012). The Euro crisis and the new impossible trinity. Bruegel Policy Contribution 2012/01. Retrieved at: http://bruegel.org/wp-content/ uploads/imported/publications/pc_2012_01_.pdf

13. Schoenmaker, D. (2015). Firmer foundations for a stronger European banking Union. Bruegel Working Paper2015/13. Retrieved at: http://bruegel.org/ wp-content/uploads/2015/11/WP-2015_132.pdf 